\title{
A Systematic Literature Review of Research Methodologies Used for Evaluation of Augmented Reality Based Learning Applications
}

\author{
Mehreen Sirshar \\ faculty of software \\ engineering \\ fatima jinnah women university \\ Rawalpindi, Pakistan \\ mehreensirshar@fjwu.edu.pk
}

\author{
Haleema Sadia Baig \\ department of software engineering \\ fatima jinnah women university \\ Rawalpindi, Pakistan \\ haleemabaig7@gmail.com
}

\author{
Syeda Hafsa Ali \\ department of software \\ engineering fatima jinnah \\ women university \\ Rawalpindi, Pakistan \\ hafsaali1803@gmail.com
}

\begin{abstract}
With the advancement in AR technology, more education-based applications are being developed using Augmented Reality, which has revolutionized the learning experience. However, in order to determine the application's impact on student's motivation, performance and their communication with the lecturer, various studies are conducted. These studies use one of the three research methodologies for data analysis and evaluation. In this systematic review, we have analyzed various research methodologies for system evaluation of the AR learning applications and recorded the student response toward the system. Also, we checked which methodology is preferred by researchers and why. A total number of 25 studies were analyzed which were published during the year of 2015 and 2019. The results indicate that most popular research technique is mixed methodology as it combines both qualitative and quantitative techniques. The purpose of this review is to offer new insights to researchers and provide them with advice about evaluation of AR applications and which tool or technique is more effective.
\end{abstract}

Keywords: augmented reality; mixed reality; learning applications; SLR; AR evaluation; research methods; AR in education

\section{INTRODUCTION}

During the past few years, there has been a rapid increase in use of Augmented Reality (AR) to ease daily tasks. Now, its application is not limited to just gaming or other leisure activities but is widely applied in other fields like healthcare, construction, and Education. In Augmented Reality real world objects are combined with virtual objects. AR system requires a certain range of data (images, videos, 3D-models) as input and represents result in both natural and synthetic light. It uses technologies like S.L.A.M and depth tracking to provide a combination of both real and virtual reality. Along with other areas its implementation in education is still limited but it has shown quite positive results by enhancing student's motivation, understanding and subject evaluation. In education it is being used for engaging and motivating students, improving teacher and student communication during lectures. Steve Chi Yi Yuan [1] has identified five potential directions for Augmented Reality in Education which are; AR books, AR games, object modeling, discovery-based learning programs and particular skills training. Such systems can easily be developed using AR tools available for both Web based applications and mobile applications, like SDKs, ZOOBRUST and Unity. AR based systems are being developed to improve educational facilities yet there is a serious need for design and development of learning activities using augmented reality.

Although application development and designing are a critical part but its testing and evaluation to determine if it fulfills the user requirements is also crucial. For the evaluation of AR based systems usually various studies are conducted which determines the user's response towards the system. Various research methods are used for data analysis of these studies. Depending on research problems, researcher's experience, type of data being manipulated and reporting audience 
[2] involved in the research, researchers have a choice of three basics methods to choose from when carrying out research. These are:

- Qualitative method

- Quantitative method

- Mixed method

In Qualitative research, descriptive and concise methods are used to produce significance and interpretation of the observed phenomena. It can further categorize into Ethnography, Narrative, Phenomenological, Grounded Theory and Case Study. Quantitative method uses statistics and numbers to describe outcomes in research. It includes Cross-Sectional, Longitudinal, Descriptive, Correlational and Experimental research methodologies.

Mixed research methodology is a hybrid approach that incorporates quantitative and qualitative approaches to obtain a complete understanding of the phenomena being investigated. Four mixed research methodologies frequently used are: Sequential explanatory design, Sequential exploratory design, Concurrent triangulation, Concurrent nested. Most frequently used research methodology used for AR based learning system is mixed research because when a researcher blends both quantitative and qualitative approaches, the system can be evaluated in a better manner.

\section{LITERATURE REVIEW}

Over the years various Augmented learning systems have been proposed and successfully implemented. In order to validate the result almost all the systems use qualitative study approach and gather data from users before and after user testing.

Peng Chen et al. [3] has reviewed 55 studies based on augmented reality in education published between year 2011 and 2016, focusing particularly on social sciences. It has been noticed that major focus of AR utilization is in higher education environments (Bachelor, 23.64\%) and compulsory education (primary, 16.36\%; Junior school, 18.18\%), with little to no work done in "Early childhood education" (5\%). Out of these 55 papers $40 \%$ covers studies in the field of science with $14.55 \%$ in "Engineering, manufacturing and construction "and "Health (7.27\%)". Similarly, the most frequently used method for research and evaluation of system is mixed methods $(40.0 \%)$, then quantitative research methods $(32.73 \%)$ and qualitative research methods $(7.27 \%)$ however during the time period between 2011 and 2016 empirical studies and quantitative research methods are used more often for sciences and engineering. These studies have shown that using AR in education has resulted in better performance and thus has motivated students towards learning.

Similarly, Hekan Tekeder et al. [4] has examined as much as 171 reviews published on Augmented Reality Applications in education between the year 2005 and 2015. Using metaanalysis method papers are selected and result obtained from each independent paper are merged to get a new viewpoint. The main purpose of the study was to check the efficiency of AR based educational applications. It has been showed that average effect size of educational AR applications is 0.677 which shows that effect is at medium level and has a positive impact on overall performance of student.

In 2019 Jenifer Chalenor et al. [5] reviewed various application of AR developed for history education and overall its impact on learning environment. Within the classroom, AR allows student to take control of their studying speed rather than assuming lecture speed, student comfortable with. $\mathrm{AR}$ in education has proved to be as a game changer yet there are certain complications like user distraction, inability to operate the system or the "Game Play" element i.e. a student may have fun using the application but may not learn.

An augmented reality (AR)-enhanced learning system is proposed by Chi Hung Teng et al. [6] that allows students to learn programming languages for 3-D application. To check the impact of this learning system on students an experiment was conducted on 34 students. All students used both of an AR-enhanced version and an ordinary version. the findings have shown that the results from enhanced version are quite promising particularly in terms of system usability, flow experience, and usage perception. also, mean value of enhanced system is higher than the other. The same trend was followed for others. In total, students with the AR-enhanced version completed 32 (i.e., 15+17) units, 
as compared to 19 (i.e., 12+7) units completed by ordinary. The results have clearly shown that enhanced version has higher success rate also students have shown more interest in AR versions which shows that this system is more efficient, user friendly and useful. Although pilot study has shown positive response yet its impact with large sample size groups must be evaluated and examined.

Kunyanuth Kularbphetton et al. [7] has presented an effective learning system for a physics classroom using AR technology. This system was designed on android platform and encourages students to use their cell phones for studying physics more conveniently. In order to test the system, quasi experimental design is employed using pretest and posttest techniques for non-randomized control group. For system evaluation Blackbox technique is used which determines the overall performance of the application by providing questionaries' to the students and the field experts. The system results are divided into two groups a) improvement in student learning capabilities b) performance evaluation and user satisfaction liabilities the application. The results of the study have shown that the mean in all aspects for students and children are 4.02 and 4.10. similarly, the standard deviation for both is also quite high peeking at 0.67 and 0.74 .

Augmented reality in classroom environments are being used to improve the students' performance and learning. a similar study was conducted on the students of secondary school in Taiwan [8]. The results are rather surprising as the students were satisfied to highest levels because they not only learned activities but also acquired the target knowledge as well.

A large number of studies have been conducted to test and evaluate the lecture efficiency when AR is used but very few systems are designed which can check how AR can influence student's motivation for learning a second language. A similar study was conducted in China [9]. For this study five Chinese collages were selected to evaluate an English vocabulary learning application developed on Augmented Reality i.e. Aursama. The keller's ARCS motivational model was adapted to asses' students. For this purpose, a semi-structured interview with open-ended questions was also used. Now to check Chinese students' response to augmented reality use in English vocabulary learning and to identify factors that define use of AR in language class, a qualitative study approach was used. For this study data gather from various interviews was analyzed and compared against purely quantitative study approach used for control group. After testing data was analyzed on the basis of interpretive paradigm of how AR influence motivational process for a second language learning. As a result, 4 out of 5 participants liked new way of presentation and showed interest in learning more about system.

Medicine is a field of science which always need a lot of effort and time so if could use AR for teaching medical students a lot of time can be saved. Using mobile Augmented Reality, a magic book was developed for neuroanatomy students [10]. With this technology users could interact with virtual learning objects in real world and its impact on medical students' academic achievement and cognitive load could be monitored. To test the results mixed method (both quantitative and qualitative methods) was applied on a total number of 70students; selected from a pool of 263 second year medical students at Ataturk medical University. 34 were randomly assigned to experimental group while remaining 36 were part of control group. Using one-way MANOVA test for analysis, a significant difference between the experimental and control group was observed. Also, in response to the system's impact on cognitive load $77 \%$ were completely satisfied, $24 \%$ were satisfied while just $3 \%$ gave a negative response. Overall response of the system was satisfactory, but it does have some limitations due to internet connectivity issues, inadequate knowledge of technology and variation of time each student was spending with learning material.

The study conducted by Y.H Yang [11] explores to integrate AR technology to support Software editing course. It also tries to compare effectiveness of online learning strategies and AR based blended learning techniques. Using a comparative research approach 103 students were selected for the study. The experimental Group learned with AR based strategies while control Group focused on online learning techniques. The findings of the study have shown that AR has a lot of potential for peer learning interaction and student motivation for learning. Even when the AR support was removed, students in experimental group showed interest in learning on the other hand, Control 
Group learners became passive as soon as support was removed. It can be summarize as when integrating AR application in education; information displayed design, amount of data displayed on mobile devices, price of the equipment and educational environment must be considered carefully to achieve a suitable learning experience.

Augmented reality can be mixed with other technologies i.e. mobile learning to produce a blended learning application. [12]. This application can be used for teaching a particular subject. The most significant part of this system is continuous revision of context by using dynamic content from various famous sources like" Wikipedia" or" YouTube". Using "Station Rotation Model", given application was developed using an open source software. This system was tested on students of age group 11-12 and has shown that almost $47 \%$ of the students using mixed learning application were able to answer $90 \%$ of questions correctly while $31 \%$ of the students using traditional teaching method answered $94.2 \%$ of the asked questions.

F S Irwansyah et al. [13] has proposed a study to show various stages of developing an AR based learning system for molecular geometry. The system follows a "Design based Approach" and the application development was done on android platform. At the end, limited number of trials were conducted which showed that the application has potential to be applied for learning Chemistry. For system evaluation 10 students were randomly selected and were asked to fill a questionnaire after completing the lab tasks with AR aid. The results of the evaluation of these lab tasks and questionnaires have shown that it has a feasibility of 70.83-92.50\%.

Yelda Turkan et al. 1 [14] has combined mobile AR with 3D visualization to study structural analysis. For this purpose, an augmented reality application is developed and to evaluate its performance a pilot study was conducted in a junior structural analysis class. Classis divided into test and control groups and their response and performance was assessed using pre and post testing techniques. The findings have shown that this application has potential to contribute towards student learning and motivation through constructive engagement and retention of information in studies.

"Human Anatomy in mobile augmented reality" or HuMar [15] is developed using mAR to make the study of human skeletal structure easier thus enhance students learning processes. After designing and development of application a pilot study was conducted using 30 science students from three different universities. The students were exposed to HuMar and after one hour of lectures they were provided with questionnaires to record their response. Then a descriptive analysis was carried out on the results. It can be said that overall, students were satisfied with HuMar performance.

In order to check if AR can help students in Mathematics Learning at higher level a study was carried out by MMath. Teresa Coimbr [16]. For this research "Design-based Research" methodology is used to discover the relation among practice, project artifacts and educational theory. In pretest phase to check if AR can actually act as a Math's enhancer students were provided with 13 tablets and 13 books and were asked to use them. At the end 10 out of 15 students answered to a survey and all of them stated that they would happily shift to 3D contents for Mathematical analysis as it "facilitates learning greatly".

In former development, augmented reality was combined with traditional learning books, also known as "magic books" for collective learning in higher education, but it had certain restrictions. So, Jorge Mart' in-Gutierrez et al. [17] worked' on development of system that give students free hand for learning and allow teachers to prevent training sessions and recommend students motivational tools for their better learning. For evaluation, 6 groups each comprising of 25 students were selected arbitrarily and were allowed to use three AR applications to support learning. They were given system usability scale (SUS) questionnaires, followed by usability and feedback surveys. SUS involves odd and even questions, where each question has different weightage. Result from surveys indicated significant increase in student's motivation which ultimately indicates acceptance of augmented reality-based learning tools by students.

Valeria Farinazzo Martins et al. [18] performed systematic' review on conference papers, papers from different journals, year wise papers specifically from last five years and made list of standard 
attributes, which appeared commonly and hence important for measuring usability of AR applications. Then for listed attributes, set of questions were established.

In first systematic review, 42 attributes were extracted while 9 attributes were found in second attempt. Also, $85.71 \%$ of attributes found in first review were present in second review. It was found that attributes that appeared mostly ten times during systematic review were: ease of use, user satisfaction, ease of learning applications and attractiveness of application.

An evaluation was performed by Jorge Joo-Nagata et al. [19] on use of mobile pedestrian navigation app and augmented reality i-e m-learning which is widely used as teaching tool now-adays similar to e-learning. Mixed-method analysis was used for this evaluation. In this regard, 143 primary school students were selected and divided into 2 groups; control and experimental. One group was given e-learning while other was given m-learning environment. Objective test was done at pre and post level, followed by satisfaction surveys and interviews. Results showed that students who worked in mlearning environment (used mobile) had better visualization of concepts and improved performance in all processes as compared to students in e-learning setup (used PC, desktop).

MRLE (mixed-reality learning environment) approach was proposed by Jared A. Franka e al. [20] in which laboratory approaches (both traditional and non-traditional) and hardware and software of mobile were merged with the aim of teaching dynamic systems and concepts to students. For effectiveness evaluation, 75 engineering students were selected and were allowed to use this approach in groups. It was shown that students who used MRLE platform had major improvement in content knowledge than those using traditional techniques. Hady Pranoto et al. [21] worked on finding of important testing methods for usability of AR applications and found that major aspects to be assessed in this regard are reliability, functionality, maintainability, portability and efficiency. Three ways to evaluate usability include 1- Testing method 2- Inspection method 3- Inquiry method. As an experiment, author used two different techniques for testing and concluded that in order to get more valid measurement, more than one evaluation technique should be applied to same application.

Ahmad Karambakhsha et al. [22] combined trained neural network (CNN) with augmented reality in order to facilitate anatomy learning in medical field. Input source in this method were gestures which can be recognized by RGB-d camera followed by 3D path tracking. Testing techniques for this include cross subject testing method and cross validation testing method. Results of testing were compared with previous work, demonstrating our technique as more accurate and have capability to add new gestures easily.

In 2016, "magic-mirror" AR-based system was developed by Meng Ma et al. [23] to facilitate medical industry by mapping anatomy of user directly on their body. They basically used In-situ visualization algorithm for augmentation of organs on real user's body. After development, precision checking and acceptability tests were performed with the help of 2 user studies containing 72 students and 7 clinicians. First study indicated precision of $0.96 \mathrm{~cm}$ and second study showed $86.1 \%$ authorization of use of magic mirror and 91.7\% of AR proficiency. In 2015, Ekrem Solak et al. [24] designed descriptive research model for determination of student's interest in AR-based language course. This model analyzed data, collected through questionnaires which was made for 130 (48 males, 82 females) undergraduates. Result of analysis revealed direct relation between student's academic accomplishments and use of AR technology.

Huseyin Uzunboylu et al. [25] summarized real life applications of augmented reality with prime focus in educational field. According to them AR is widely used now-a-days in defense, industry, sports, entertainment, medicine and trade. It plays vital role in education, with capability to generate interactive and collaborative environment for enhanced learning. Nils Petersen et al. [26] provided a comprehensive approach; cognitive augmented reality whose main focus was the development of AR-based software for functional activities. This was the first approach that combined classical augmented reality with machine learning and resulted in cognitive system. G. Dini et al. [27] concluded in their research that, in TES (Through-life Engineering services), Augmented reality works as an effective tool, since it provides user their required information 
directly in real environment. Major application of this field are in maintenance, repairing, diagnostics, testing, safety and setup activities.

\section{METHODOLOGY}

\section{A. Research Questions}

Over the past years, AR has emerged to be a revolutionary technique which has vast application particularly in education. Many studies have been published which cover its advantages, limitations and challenges; we may face in future. But little work is done in regard of how these systems are evaluated and tested along with techniques being used for development and limitations of the present AR systems. In this regard, this study addresses following questions.

- What techniques, tools or algorithms are being used in the development of AR based educational or learning systems?

- What is the general user response towards the application or how accurate does the application works?

- What are the limitations of discussed AR based learning systems?

\section{B. Search Strategy}

In this systematic analysis, the framework of proposed system used by Kitchenhem et al. is as follows:

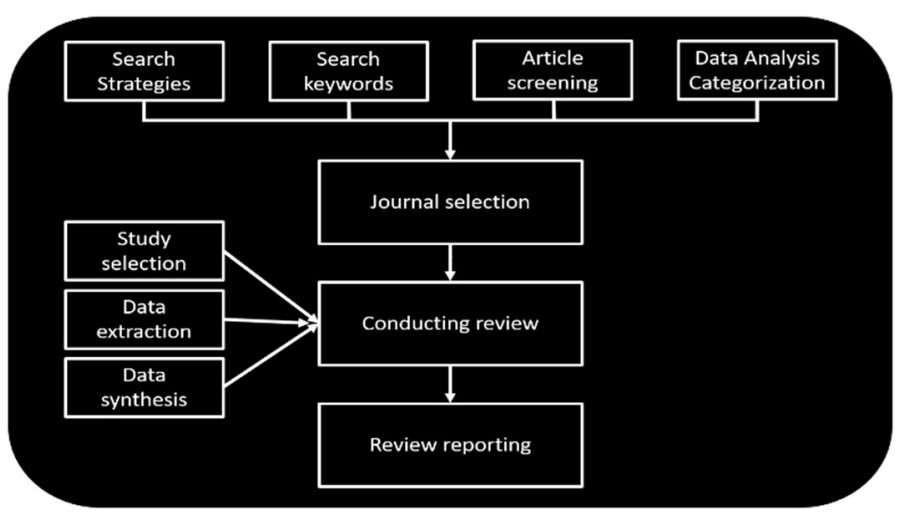

Figure 1. Framework of proposed system.

Step 1: journal selection

The main concern behind initiation of this step is to gather and choose most relevant journals for systematic quality analysis of quality techniques. In order to keep the process methodologically strong and consistent, we have set a special selection criterion for journals. Using the google scholar, different field relevant journals are selected from specific libraries including: "IEEE Explore", "ACMA", "Springer", "Elsevier", "Science Direct" and papers published in "International Conference of Computer Vision". These libraries are selected due to a number of key factors, mainly on the basis of their ranking and impact factor value. Moreover, only those papers were selected which used qualitative, quantitative or mixed research methodologies for the result evaluation because these methods tend to provide most accurate results to approve or disapprove a hypothesis in experimental research. 


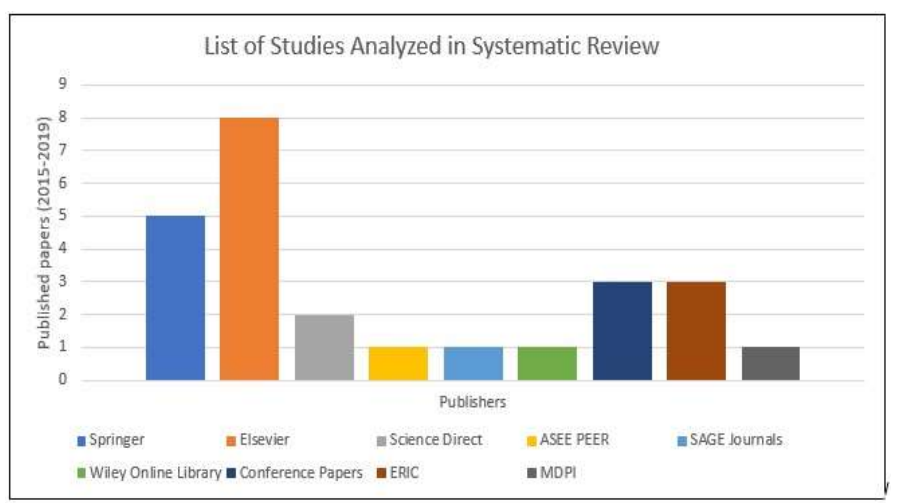

Figure 2. List of studies analyzed during systematic review.

For journal searching, "educational technology" category was selected in Google scholar's h5 index. Keywords used for paper searching comprised of "Augmented reality learning systems", "Educational applications of AR", "AR in education", "Quality evaluation of AR learning systems", "Evaluation methods for AR systems and applications", "Review of AR application" and other such tags and keywords.

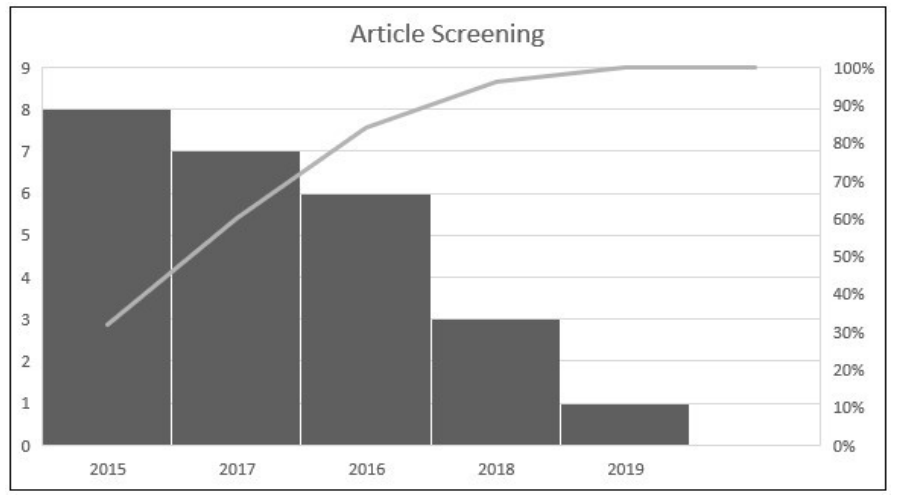

Figure 3. Yearly based article screening.

In article screening, selection and rejection criteria; "inclusion and exclusion criteria" is defined.

Table 1. EXCLUSION CRITERIA FOR PAPERS.

\begin{tabular}{cc}
\hline $\begin{array}{c}\text { Sr } \\
\text { No. }\end{array}$ & Exclusion Criteria \\
\hline 01 & Articles published before 2015 \\
\hline 02 & $\begin{array}{c}\text { Studies which are not identified as "article" } \\
\text { in selected journals. }\end{array}$ \\
\hline 03 & Articles written in any language other than \\
English
\end{tabular}




\begin{tabular}{cc}
\hline 02 & $\begin{array}{c}\text { Studies describing framework for AR based } \\
\text { applications in Education. }\end{array}$ \\
\hline 03 & $\begin{array}{c}\text { Only those related articles which are written } \\
\text { in English }\end{array}$ \\
\hline 04 & Related articles with access of full text. \\
\hline 05 & $\begin{array}{c}\text { Studies which present evaluation method for } \\
\text { AR Learning systems in different scenarios } \\
\text { and use various research methods. }\end{array}$ \\
\hline
\end{tabular}

In the last part of "journal selection", categories and subcategories are defined for every question. During the systematic analysis, new subcategories may emerge which will refine the relevant information. For the research questions as defined earlier, various analysis categories are provided as follow:

- How development of Augmented Reality based educational or learning systems is done?

(a) Different types of platforms use for AR applicationdevelopment; (b) type of hardware use for visualization in real time;

- What is the general user response towards the application or how accurate does the application works?

(a) Different research methodologies use for Applicationevaluation; (b) accuracy of the proposed system by conducting experiments.

- What are the limitations of discussed AR-based learning systems? The proposed analysis will identify limitations of discussed systems on student's overall performance and learning gain, application's functionality limitation and the problems which may occur when AR is used in combination with different devices.

\section{Conducting Review and Data Analysis}

In this portion, the results obtained at the end of the study are discussed in detail. Based on inclusion and exclusion criteria, 25 studies from selected journals were included this analysis. Data extraction and synthesis was done manually by carefully studying all the selected articles. The findings of the review are identified and presented as the response to defined questions. Since the given papers do not follow any standard theme so individual findings extracted from each paper are identified. Most crucial observations and answers to the defined question with respect to each paper are summarized in the following table.

Table 3. AN OVERVIEW OF AR BASED EDUCATIONAL LEARNING.

\begin{tabular}{|c|c|c|c|c|}
\hline $\begin{array}{l}\text { Research } \\
\text { Studies } \\
\text { (Authorsand } \\
\text { Year) }\end{array}$ & Technology used & $\begin{array}{l}\text { Data collection } \\
\text { and analysis }\end{array}$ & $\begin{array}{l}\text { User response and } \\
\text { results accuracy }\end{array}$ & Limitations \\
\hline $\begin{array}{l}\text { PengChen et } \\
\text { al.(2017) }\end{array}$ & Nil (review paper) & $\begin{array}{l}\text { Qualitative } \\
\text { research }\end{array}$ & Positive & $\begin{array}{l}\text { Timeframe of research } \\
\text { is limited. Moreover, } \\
\text { data sample size is } \\
\text { small. }\end{array}$ \\
\hline $\begin{array}{l}\text { Hekan Tekeder } \\
\text { et al.(2016) }\end{array}$ & Nil (review paper) & Meta-analysis & $\begin{array}{l}\text { Positive Average } \\
\text { effect size of } \\
\text { application is } 0.677\end{array}$ & $\begin{array}{l}\text { AR application in } \\
\text { social sciences is } \\
\text { limited as major focus }\end{array}$ \\
\hline
\end{tabular}


is natural sciences also few AR based applications are developed for handicapped.

\begin{tabular}{|c|c|c|c|c|}
\hline $\begin{array}{l}\text { Jenifer } \\
\text { Chalenor } \\
\text { al.(2019) }\end{array}$ & J/A & $\begin{array}{l}\text { Survey research } \\
\text { (quantitative } \\
\text { method) }\end{array}$ & $\begin{array}{l}\text { Positive Students } \\
\text { who used AR } \\
\text { showed higher score } \\
\text { in exams. }\end{array}$ & $\begin{array}{l}\text { Few empirical research } \\
\text { studies are performed } \\
\text { for AR use in } \\
\text { education. }\end{array}$ \\
\hline $\begin{array}{l}\text { Chi Hung Teng } \\
\text { et al. (2018) }\end{array}$ & $\begin{array}{l}\text { Holistic window for 3D } \\
\text { perspective view } \\
\text { Command cards for } \\
\text { program writing. }\end{array}$ & $\begin{array}{l}\text { Experimental } \\
\text { research } \\
\text { (quantitative } \\
\text { method) }\end{array}$ & $\begin{array}{l}\text { Mean value of system } \\
\text { usability for AR } \\
\text { version is } 71.02 \text {, with } \\
\text { positive results in } \\
\text { learning efficiency, } \\
\text { usage perception and } \\
\text { flow experience. }\end{array}$ & $\begin{array}{l}\text { Sample size of study is } \\
\text { limited which } \\
\text { conducted as } \\
\text { shortterm study. These } \\
\text { are not sufficient to } \\
\text { examine application } \\
\text { impact on learning and } \\
\text { student's consistency } \\
\text { with study. }\end{array}$ \\
\hline $\begin{array}{l}\text { Kunyanuth } \\
\text { Kularbphetton } \\
\text { et al. (2017) }\end{array}$ & $\begin{array}{l}\text { Android platform for } \\
\text { application } \\
\text { development. } \\
\text { Cell phone for usage. }\end{array}$ & $\begin{array}{l}\text { Quasi } \\
\text { experimental } \\
\text { design for non- } \\
\text { randomized } \\
\text { control group. } \\
\text { Black box } \\
\text { technique is use } \\
\text { for system } \\
\text { evaluation. }\end{array}$ & $\begin{array}{l}\text { Student showed a } \\
\text { positively high } \\
\text { attitude toward } \\
\text { learning with rating } \\
\text { above4.05. }\end{array}$ & $\begin{array}{l}\text { The system is } \\
\text { restricted to a single } \\
\text { course also no } \\
\text { particular mechanism } \\
\text { is developed for } \\
\text { intelligently } \\
\text { identifying student's } \\
\text { learning preferences } \\
\text { based upon their } \\
\text { interest on social } \\
\text { networking sites. }\end{array}$ \\
\hline $\begin{array}{l}\text { Kunyanuth } \\
\text { Kularbphetton } \\
\text { et al. (2018) }\end{array}$ & $\begin{array}{l}\text { Rapid application } \\
\text { development tool used } \\
\text { for AR mobile } \\
\text { application } \\
\text { development. }\end{array}$ & $\begin{array}{l}\text { Quasi- } \\
\text { experimental } \\
\text { research. }\end{array}$ & $\begin{array}{l}\text { Level of student } \\
\text { satisfaction toward } \\
\text { teaching, learning } \\
\text { and overall with AR } \\
\text { application is quite } \\
\text { high with mean value } \\
\text { of } 4.63 \text {. }\end{array}$ & $\begin{array}{l}\text { Lack of adaptive } \\
\text { learning approach for } \\
\text { learners. }\end{array}$ \\
\hline $\begin{array}{l}\text { Shanshan Li et } \\
\text { al. (2015) }\end{array}$ & $\begin{array}{l}\text { "Aurasma" Ar based } \\
\text { application available } \\
\text { for Android and IOS } \\
\text { systems. }\end{array}$ & $\begin{array}{ll}\text { Qualitative } & \text { study } \\
\text { approach } & \text { (semi- } \\
\text { structured } & \\
\text { interview } & \text { with }\end{array}$ & $\begin{array}{l}4 \text { out of } 5 \\
\text { participants "liked" } \\
\text { the application. }\end{array}$ & $\begin{array}{l}\text { AR based learning } \\
\text { material is still limited } \\
\text { which can impact } \\
\text { student's motivation }\end{array}$ \\
\hline
\end{tabular}


openminded

questions).

\begin{tabular}{lllll}
\hline Samet Kapakin "magic book" using & Mixed research & Students who used \\
et al. (2016) & mobile augmented & method with 70 & mAR for anatomy \\
& reality technology. & random samples. & showed success rate \\
& & & of 78.14 compare to \\
& & & 68.344 rate in control \\
& & & group students.
\end{tabular}

\begin{tabular}{lllll}
\hline Y.H Wang & AR interaction via & Quasi- & Learners revealed \\
$(2017)$ & personnel mobile & experimental & positive feedback \\
& devices & design using towards AR based \\
& & comparative test learning system \\
& data and empirical & \\
& & \\
& & \\
& &
\end{tabular}

\begin{tabular}{|c|c|c|c|c|}
\hline \multirow{12}{*}{$\begin{array}{l}\text { Marina } \\
\text { Delianidi et al. } \\
\text { (2016) }\end{array}$} & Mixed-learning & \multirow{3}{*}{$\begin{array}{l}\text { Experimental } \\
\text { research with each } \\
\text { of the twogroup }\end{array}$} & Participants majority & AR implementation is \\
\hline & method. & & expressed & limited to particular \\
\hline & interconnection with & & satisfaction and & subjects. There is lack \\
\hline & dynamic internet & \multirow{3}{*}{$\begin{array}{l}\text { containing } \\
\text { members. }\end{array}$} & positive & of use of advanced \\
\hline & platform & & regarding the subject & digital content search, \\
\hline & communication & & understanding using & adaptive learning and \\
\hline & interfaces & & AR. $82.6 \%$ correct & internet \\
\hline & visualization & & answers & technologies \\
\hline & \multicolumn{2}{|l|}{ augmented reality). } & experiment group & combination with AR. \\
\hline & & & and control group & \\
\hline & & & gave $80.8 \%$ correct & \\
\hline & & & answers. & \\
\hline \multirow{6}{*}{$\begin{array}{l}\text { F S Irwansyah } \\
\text { et al. (2018) }\end{array}$} & Using Android & \multirow{2}{*}{$\begin{array}{ll}\text { Design } & \text { based } \\
\text { research } & \text { with }\end{array}$} & \multirow{6}{*}{$\begin{array}{l}72.50 \% \text { of } \\
\text { respondents believed } \\
\text { that AR application } \\
\text { can increase students } \\
\text { learning motivation. }\end{array}$} & \multirow{6}{*}{$\begin{array}{l}\text { Application is } \\
\text { analyzed on the basis } \\
\text { of the results obtained } \\
\text { from a limited trial. }\end{array}$} \\
\hline & operating system for & & & \\
\hline & application & \multirow{3}{*}{$\begin{array}{l}\text { quantitative } \\
\text { method is used for } \\
\text { assessment of }\end{array}$} & & \\
\hline & development of AR & & & \\
\hline & technology-based & & & \\
\hline & learning media. & respondents. & & \\
\hline \multirow{6}{*}{$\begin{array}{l}\text { Yelda Turkan et } \\
\text { al. (2017) }\end{array}$} & Mobile augmented & \multirow{2}{*}{$\begin{array}{l}\text { Quasi- } \\
\text { experimental }\end{array}$} & \multirow{6}{*}{$\begin{array}{l}\text { The effectiveness of } \\
\text { AR application has } \\
\text { shown a mean value } \\
\text { of } 6.84 \text { in posttest by } \\
\text { experimental group }\end{array}$} & \multirow{6}{*}{$\begin{array}{l}\text { Application does not } \\
\text { yield expected results } \\
\text { with no instant } \\
\text { feedback feature. }\end{array}$} \\
\hline & reality and interactive & & & \\
\hline & 3D visualization & design & & \\
\hline & \multirow[t]{3}{*}{ technology. } & adopted. & & \\
\hline & & sources included & & \\
\hline & & pre-test, post-test & & \\
\hline
\end{tabular}

toward learning in a negative way.

Student's access to material is limited to internet access also application rquires particular technical features in smart phones for operability.

Lack of experience with $\mathrm{AR}$ and slow internet connection can affect the implementation.

Learning Interface size was also small.

\section{西}




\begin{tabular}{|c|c|c|c|c|}
\hline & & $\begin{array}{l}\text { and an attitude } \\
\text { survey. }\end{array}$ & $\begin{array}{l}\text { and for control group } \\
\text { its } \\
6.66 \text {. }\end{array}$ & \\
\hline $\begin{array}{l}\text { Siti Salmi } \\
\text { Jamali et al. } \\
(2015)\end{array}$ & $\begin{array}{l}\text { "HuMAR" } \\
\text { development using } \\
\text { mobile augmented } \\
\text { reality }\end{array}$ & $\begin{array}{l}\text { Experimental } \\
\text { method with } \\
\text { science's students } \\
\text { from three } \\
\text { different } \\
\text { universities. }\end{array}$ & $\begin{array}{l}\text { For learning } \\
\text { improvement and } \\
\text { enhancement of } \\
\text { understanding a } \\
\text { mean value } 4.43 \text { and } \\
4.27 \text { was obtained. } \\
\text { Mean growth rate in } \\
\text { traditional learning is } \\
\text {-8.067 and mean } \\
\text { performance score } \\
\text { using HuMAR } \\
\text { is -14.933 }\end{array}$ & $\begin{array}{l}\text { Limited motivational } \\
\text { studies of mAR as } \\
\text { learning method. }\end{array}$ \\
\hline $\begin{array}{l}\text { Teresa Coimbra } \\
\text { et al. (2015) }\end{array}$ & $\begin{array}{l}\text { 3D elements creation, } \\
\text { programming in AR } \\
\text { application and } \\
\text { publishing. }\end{array}$ & $\begin{array}{l}\text { Design-based } \\
\text { research with } \\
\text { mixed research } \\
\text { methodology. }\end{array}$ & $\begin{array}{l}\text { At the end of pre-test } \\
\text { session10ount of } 13 \\
\text { students stated that } \\
\text { the application } \\
\text { facilitates learning } \\
\text { while answering to a } \\
\text { survey. }\end{array}$ & $\begin{array}{l}\text { Application } \\
\text { sensitive towards } \\
\text { brightness conditions. } \\
\text { Sometimes show } \\
\text { difficulty in auto- } \\
\text { focus. }\end{array}$ \\
\hline $\begin{array}{l}\text { JorgeMart et } \\
\text { al.(2015) }\end{array}$ & $\begin{array}{l}\text { "ElectARmanual", } \\
\text { "ELECT3D", } \\
\text { "ElectAR" Used } \\
\text { computer } \\
\text { vision techniques. } \\
\text { For 3D animation } \\
\text { and model } \\
\text { creation 3D studio } \\
\text { software is used. }\end{array}$ & $\begin{array}{l}\text { System usability } \\
\text { scale } \\
\text { questionnaires } \\
\text { (quantitative } \\
\text { method) were } \\
\text { used for } \\
\text { measuring } \\
\text { usability. }\end{array}$ & $\begin{array}{l}\text { All the students } \\
\text { considered these } \\
\text { applications a great } \\
\text { help for learning. }\end{array}$ & $\begin{array}{l}\text { No study was } \\
\text { conducted for } \\
\text { analyzing the impact } \\
\text { of AR learning tool on } \\
\text { students' academic } \\
\text { performance and } \\
\text { memory. }\end{array}$ \\
\hline $\begin{array}{l}\text { Valeria } \\
\text { Farinazzo } \\
\text { Martinset al. } \\
(2015)\end{array}$ & $\begin{array}{l}\text { List of attributes for } \\
\text { measuring usability of } \\
\text { AR application is } \\
\text { extracted. }\end{array}$ & $\begin{array}{l}\text { Questionaries' is } \\
\text { developed based } \\
\text { on usability } \\
\text { attributes used in } \\
\text { AR. }\end{array}$ & $\begin{array}{l}94 \% \text { of researched } \\
\text { papers have used the } \\
\text { word "Usability" and } \\
\text { "Augmented } \\
\text { Reality" but did not } \\
\text { cover the subject. }\end{array}$ & $\begin{array}{l}\text { No separate study is } \\
\text { conducted to evaluate } \\
\text { usability of mAR. }\end{array}$ \\
\hline $\begin{array}{l}\text { Jorge Joo- } \\
\text { Nagata et al. } \\
(2017)\end{array}$ & $\begin{array}{lr}\text { Mobile } & \text { pedestrian } \\
\text { navigation } & \text { and } \\
\text { augmented } & \text { reality in }\end{array}$ & $\begin{array}{l}\text { Mixed method } \\
\text { analysis was done } \\
\text { with pre and post } \\
\text { testing, followed }\end{array}$ & $\begin{array}{l}\text { its values for m- } \\
\text { learning and } \\
\text { elearning is shown to }\end{array}$ & $\begin{array}{l}\text { No particular } \\
\text { information about } \\
\text { student behavior in }\end{array}$ \\
\hline
\end{tabular}




\begin{tabular}{|c|c|c|c|c|}
\hline & $\begin{array}{l}\text { mobile } \\
\text { contexts. }\end{array}$ & $\begin{array}{l}\text { by satisfaction } \\
\text { surveys and } \\
\text { interviews. }\end{array}$ & $\begin{array}{l}\text { be }-14.956 \text { and }-10.621 \\
\text { respectively. }\end{array}$ & $\begin{array}{l}\text { different territorial and } \\
\text { thematic contexts. }\end{array}$ \\
\hline $\begin{array}{l}\text { Jared A. Franka } \\
\text { et al. (2017) }\end{array}$ & $\begin{array}{l}\text { Mixed reality learning } \\
\text { environment by } \\
\text { combining laboratory } \\
\text { approaches with } \\
\text { mobile hardware and } \\
\text { software. }\end{array}$ & $\begin{array}{l}\text { For user } \\
\text { experience } \\
\text { assessment, } \\
\text { questionnaire } \\
\text { inspired from } \\
\text { poststudy system } \\
\text { usability } \\
\text { Questionnaire is } \\
\text { used. }\end{array}$ & $\begin{array}{l}\text { Out of } 69 \% \text { of } \\
\text { participants who } \\
\text { commented on the } \\
\text { system, } 73.5 \% \\
\text { praised the system. }\end{array}$ & $\begin{array}{l}\text { Some usability issues } \\
\text { in the navigation of the } \\
\text { application interface } \\
\text { were reported by } \\
\text { prototype testers. }\end{array}$ \\
\hline $\begin{array}{l}\text { Hady Pranoto } \\
\text { et al. (2017) }\end{array}$ & $\begin{array}{l}\text { Induction method for } \\
\text { evaluating various } \\
\text { usability testing } \\
\text { methods. }\end{array}$ & $\begin{array}{l}\text { Using inquiry } \\
\text { method } 10 \\
\text { respondents were } \\
\text { interviewed to } \\
\text { measure usability } \\
\text { of three AR } \\
\text { applications. }\end{array}$ & N/A & $\begin{array}{l}\text { Evaluation technique } \\
\text { did not measure user } \\
\text { perception, objective } \\
\text { measurement and } \\
\text { expert evaluation. }\end{array}$ \\
\hline $\begin{array}{l}\text { Ahmad } \\
\text { Karambakhsha } \\
\text { et al. (2019) }\end{array}$ & $\begin{array}{l}\text { Convolutional neural } \\
\text { networks in } \\
\text { combination with AR } \\
\text { using Hololens to } \\
\text { simulate scenarios. }\end{array}$ & $\begin{array}{l}\text { Cross subject } \\
\text { method and cross } \\
\text { validation method } \\
\text { was used. }\end{array}$ & $\begin{array}{l}\text { When compare with } \\
\text { 3D array the } \\
\text { proposed } \text { CNN } \\
\text { approach shows } \\
\text { mean value of } 0.93 \\
\text { and } 0.97 \text { for cross- } \\
\text { validation and } \\
\text { subject testing } \\
\text { method. }\end{array}$ & $\begin{array}{l}\text { Some preprocessing } \\
\text { methods are still } \\
\text { manual which are } \\
\text { needed to be } \\
\text { automated. }\end{array}$ \\
\hline $\begin{array}{l}\text { Meng Ma et al. } \\
\text { (2016) }\end{array}$ & $\begin{array}{l}\text { "magic mirror" for in- } \\
\text { situ visualization of } \\
\text { anatomy using RGB-D } \\
\text { sensor. }\end{array}$ & $\begin{array}{l}\text { Likert scale was } \\
\text { used for survey- } \\
\text { based research. }\end{array}$ & $\begin{array}{l}\text { Study indicate } 86.1 \% \\
\text { approval for } \\
\text { educational value } \\
\text { and } 91.7 \% \text { approval } \\
\text { for AR capability of } \\
\text { displaying organs in } \\
\text { 3D. }\end{array}$ & $\begin{array}{l}\text { Accessibility of system } \\
\text { is limited due to } \\
\text { special requirements } \\
\text { like large screen and } \\
\text { stand. }\end{array}$ \\
\hline $\begin{array}{l}\text { Ekrem Solak et } \\
\text { al. (2015) }\end{array}$ & $\begin{array}{l}\text { Turkish version of } \\
\text { material motivation } \\
\text { survey (designed with } \\
\text { AR technology) was } \\
\text { used. }\end{array}$ & $\begin{array}{l}\text { Descriptive } \\
\text { research model } \\
\text { was used to } \\
\text { describe existing } \\
\text { situation. }\end{array}$ & $\begin{array}{l}\text { Student response } \\
\text { towards the } \\
\text { application was quite } \\
\text { high with mean value } \\
\text { of } 3.38 \text { with student }\end{array}$ & $\begin{array}{l}\text { No experimental study } \\
\text { is conducted for AR } \\
\text { application } \\
\text { effectiveness on } \\
\text { various age groups. }\end{array}$ \\
\hline
\end{tabular}


satisfaction toward

lesson.

\begin{tabular}{|c|c|c|c|c|}
\hline Huseyin & $\mathrm{N} / \mathrm{A}$ & Systematic & $\mathrm{N} / \mathrm{A}$ & Most $\quad$ reported \\
\hline Uzunboyluet & & review & AR & limitation out of 33 \\
\hline al. (2016) & & trends in & & studies is considered \\
\hline & & education. & & to be difficulty in \\
\hline & & & & maintaining \\
\hline & & & & superimposed \\
\hline & & & & information reported \\
\hline & & & & in 3 studies. \\
\hline
\end{tabular}

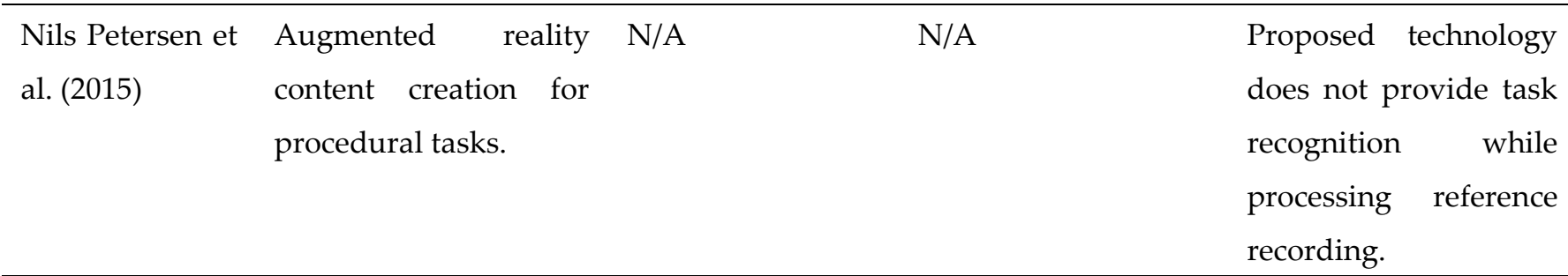

G. Dini et al. N/A

(2015)

Review recent
application to
provide
comprehensive
survey.

Technical challenges being faced include usability and portability of hardware. Limited peripheral visibility can cause safety problems.

\section{DISCUSSION AND CONCLUSION}

Augmented Reality has a lot of potential in education. Its use in a classroom environment can led to development of various positive traits in students and may even fill the communication gap between the instructors and their students. This review focuses on the evaluation of these applications and systems to emphasize their impact in education and how they can revolutionize the whole concept of education and lecture. Although a lot has been done in this domain, there is still a desperate need for development of AR based instructional design methods for different tools. Moreover, all studies conducted for the evaluation of the systems comprise of rather smaller control and experiment groups. This can widely affect the results and accuracy of the system.

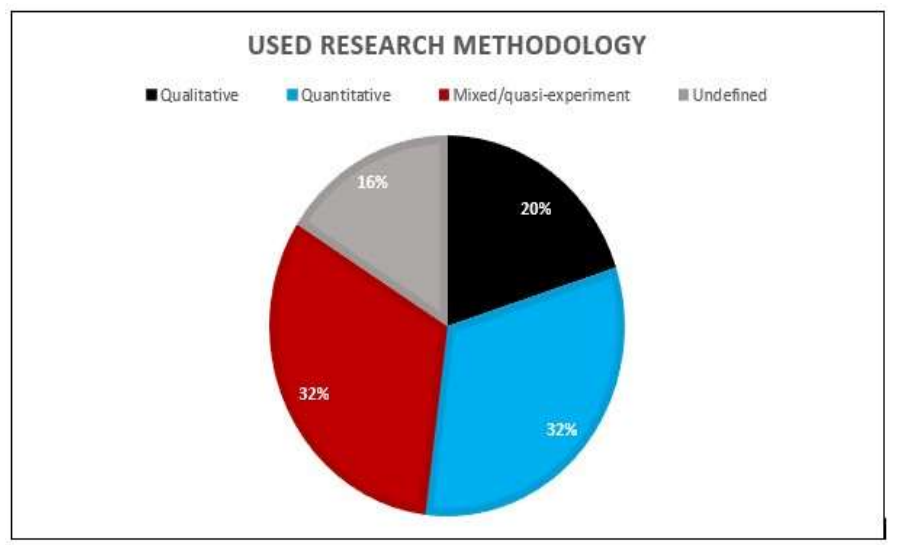


Figure 4. Ratio of used research methodologies .

To summarize the study, we can identify the core findings;

which include: (a) majority of AR applications use Mixed and Quantitative methodology for data analysis and system evaluation, in the given review almost same number of studies have used the two techniques. Out of 25 studies 8 studies have used different types of quantitative and mixed method while 5 used qualitative research. (b) most of the studies were conducted on small groups with limited dataset obtained. This can cause hindrance in determining the correct results and may affect accuracy of the system. (c) there are no particular studies conducted for AR educational application and its impact on students of various age group. Therefore, the research spectrum must be broadened to evaluate and conduct studies for "child early education".

In conclusion, given study elaborates various research methods use for AR application and data analysis. Moreover, it discusses the impact of various methodologies in determining the accuracy and performance of the system. The detailed table provide various limitations faced by researchers and developers during AR implementation which can be provided as quite useful for future work.

\section{REFERENCES}

[1] Yuen, S. C. Y., Yaoyuneyong, G., Johnson, E. (2011). Augmented reality: An overview and five directions for AR in education. Journal of Educational Technology Development and Exchange (JETDE), 4(1).

[2] Creswell, J. W. (2003). RESEARCH DESIGN.

[3] Chen, P., Liu, X., Cheng, W., \& Huang, R. (2017). A review of using Augmented Reality in Education from 2011 to 2016. In Innovations in smart learning (pp. 13-18). Springer, Singapore.

[4] Tekedere, H., \& Goke, H. (2016). Examining the Effectiveness of" Augmented Reality Applications in Education: A Meta-Analysis. International Journal of Environmental and Science Education, 11(16), 94699481.

[5] Challenor, J., \& Ma, M. (2019). A Review of Augmented Reality Applications for History Education and Heritage Visualization. Multimodal Technologies and Interaction, 3(2), 39.

[6] Teng, C. H., Chen, J. Y., \& Chen, Z. H. (2018). Impact of augmented reality on programming language learning: Efficiency and perception. Journal of Educational Computing Research, 56(2), 254-271.

[7] Kularbphettong, K., \& Limphoemsuk, N. (2017). The effective of learning by augmented reality on Android platform. In E-Learning, EEducation, and Online Training (pp. 111-118). Springer, Cham.

[8] Kularbphettong, K., Roonrakwit, P., \& Chutrtong, J. (2018, July). Effectiveness of enhancing classroom by using augmented reality technology. In International Conference on Applied Human Factors and Ergonomics (pp. 125-133). Springer, Cham

[9] Li, S., Chen, Y., \& Vorvoreanu, M. (2015). A pilot study exploring augmented reality to increase motivation of Chinese college students learning English. The ASEE Computers in Education (CoED) Journal, 6(1), 23.

[10] Kuc," uk, S., Kapakin, S., \& G" oktas , Y. (2016). Learning anatomy via“ mobile augmented reality: effects on achievement and cognitive load. Anatomical sciences education, 9(5), 411-421.

[11] Wang, Y. H. (2017). Using augmented reality to support a software editing course for college students. Journal of Computer Assisted Learning, 33(5), 532-546.

[12] Delianidi, M., Papanikolaou, A.,\& Ilioudis, C. (2016). A mobile augmented reality (mAR) blended learning application for primary school pupils. In 1st International Association for Blended Learning Conference (IABL 2016), Kavala, Greece.

[13] Irwansyah, F. S., Yusuf, Y. M., Farida, I., \& Ramdhani, M. A. (2018, January). Augmented reality (AR) technology on the android operating system in chemistry learning. In IOP conference series: Materials science and engineering (Vol. 288, No. 1, p. 012068). IOP Publishing.

[14] Turkan, Y., Radkowski, R., Karabulut-Ilgu, A., Behzadan, A. H., \& Chen, A. (2017). Mobile augmented reality for teaching structural analysis. Advanced Engineering Informatics, 34, 90-100.

[15] Jamali, S. S., Shiratuddin, M. F., Wong, K. W., \& Oskam, C. L. (2015). Utilising mobile-augmented reality for learning human anatomy. Procedia-Social and Behavioral Sciences, 197, 659-668.

[16] Coimbra, M. T., Cardoso, T., \& Mateus, A. (2015). Augmented reality: an enhancer for higher education students in math's learning? Procedia Computer Science, 67, 332-339.

[17] Mart'in-Gutierrez, J., Fabiani, P., Benesova, W., Meneses, M. D., \&' Mora, C. E. (2015). Augmented reality to promote collaborative and autonomous learning in higher education. Computers in human behavior, 51, $752-761$

[18] Martins, V. F., Kirner, T. G., \& Kirner, C. (2015, August). Subjective usability evaluation criteria of augmented reality applications. In International Conference on Virtual, Augmented and Mixed Reality (pp. 39-48). Springer, Cham. 
[19] Joo-Nagata, J., Abad, F. M., Giner, J. G. B., \& Garc'1a-Penalvo, F. J. (2017). Augmented reality and pedestrian navigation through its implementation in m-learning and e-learning: Evaluation of an educational program in Chile. Computers \& Education, 111, 1-17.

[20] Frank, J. A., \& Kapila, V. (2017). Mixed-reality learning environments: Integrating mobile interfaces with laboratory test-beds. Computers \& Education, 110, 88-104.

[21] Pranoto, H., Tho, C., Warnars, H. L. H. S., Abdurachman, E., Gaol, F. L., \& Soewito, B. (2017, November). Usability testing method in augmented reality application. In 2017 International Conference on Information Management and Technology (ICIMTech) (pp. 181-186). IEEE.

[22] Karambakhsh, A., Kamel, A., Sheng, B., Li, P., Yang, P., \& Feng, D. D. (2019). Deep gesture interaction for augmented anatomy learning. International Journal of Information Management, 45, 328-336.

[23] Ma, M., Fallavollita, P., Seelbach, I., Von Der Heide, A. M., Euler, E., Waschke, J., \& Navab, N. (2016). Personalized augmented reality for anatomy education. Clinical Anatomy, 29(4), 446-453.

[24] Solak, E., \& Cakir, R. (2015). Exploring the Effect of Materials Designed with Augmented Reality on Language Learners' Vocabulary Learning. Journal of Educators Online, 12(2), 50-72.

[25] Uzunboylu, H., \& Yildız, E. (2016). Augmented reality research and applications in education. New Trends and Issues Proceedings on Humanities and Social Sciences, (11), 238-43.

[26] Petersen, N., \& Stricker, D. (2015). Cognitive augmented reality. Computers \& Graphics, 53, 82-91.

[27] Dini, G., \& Dalle Mura, M. (2015). Application of augmented reality techniques in through-life engineering services. Procedia Cirp, 38, 1423. 